\title{
Identifikacija lokalnih ekonomskih djelatnosti u Hrvatskoj primjenom Ginijeva koeficijenta
}

\author{
Zdenko Braičić \\ Sveučilište u Zagrebu, Učiteljski fakultet, Odsjek u Petrinji, Hrvatska \\ e-mail:zdenko.braicic@ufzg.hr
}

SAŽETAK Polazna točka u ovom radu podjela je ekonomskih djelatnosti s obzirom na njihovu geografsku distribuciju. Porter (2003.) razlikuje nadregionalne djelatnosti (engl. traded), zatim djelatnosti ovisne o prirodnim resursima i lokalne djelatnosti. Cilj je rada utvrditi lokalne ekonomske djelatnosti (područja djelatnosti) u Hrvatskoj, odnosno djelatnosti čiji je raspored u prostoru prilagođen prostornoj distribuciji stanovništva. U tu je svrhu predložena modificirana primjena Ginijeva koeficijenta, populacijski Ginijev koeficijent, koji geografsku distribuciju zaposlenosti u pojedinim djelatnostima uspoređuje $s$ geografskom distribucijom stanovništva. $\mathrm{Na}$ taj su način utvrđene ekonomske djelatnosti koje su po županijama Hrvatske distribuirane sukladno distribuciji stanovništva (2017.): obrazovanje; opskrba električnom energijom, plinom i parom te klimatizacija; građevinarstvo; opskrba vodom, uklanjanje otpadnih voda; zdravstvena zaštita i socijalna skrb itd. U drugom dijelu rada identificiraju se djelatnosti koje su po općinama i gradovima Hrvatske i njezinim županijama distribuirane slično stanovništvu. Obrazovanje je djelatnost čija geografska distribucija neznatno odstupa od distribucije stanovništva Hrvatske po općinama i gradovima. U radu je ukazano i na postojanje razlika između lokalnih i ostalih djelatnosti u pogledu zaposlenosti.

Ključne riječi: geografska distribucija, lokalne djelatnosti, stanovništvo, populacijski Ginijev koeficijent, Hrvatska. 


\section{Uvod}

Prostorni raspored ekonomskih aktivnosti rezultat je utjecaja brojnih lokacijskih čimbenika - prirodnih, demografskih, ekonomskih, tehničkih, političkih, ekoloških, povijesnih (Cvitanović, 2002.; Lončar i Stiperski, 2019.). Pojedine ekonomske aktivnosti relativno su ravnomjerno raspoređene u prostoru, dok su druge više koncentrirane. Stanovništvo je svakako jedan od značajnih čimbenika lokacije ekonomskih aktivnosti u prostoru. $S$ jedne strane ono je izvor radne snage (proizvodna funkcija stanovništva), a s druge strane predstavlja tržište (potrošačka funkcija). Dok se pojam radne snage odnosi samo na ekonomski aktivan dio ukupnog stanovništva, u potrošnji (tržište) sudjeluje ukupno stanovništvo, ekonomski aktivno i uzdržavano (Wertheimer-Baletić, 1982.). Pritom nije značajan samo prostorni razmještaj stanovništtva, odnosno njegova brojnost, već i obilježja stanovništva kao što su obrazovna i dobna struktura, cijena radne snage i drugo, pa je stanovništvo ujedno i demografski i ekonomski lokacijski čimbenik. Važnost stanovništva, odnosno njegovih socioekonomskih i drugih obilježja kao lokacijskih čimbenika ovisi o značajkama pojedine ekonomske djelatnosti, tj. nije isto je li posrijedi trgovina na malo, prerađivačka industrija, financijsko poslovanje ili neka druga ekonomska djelatnost. Primjerice, pojedina su istraživanja utvrdila da je blizina kvalificirane i obrazovane radne snage među najvažnijim lokacijskim čimbenicima industrije u Hrvatskoj, značajnijim od blizine kupaca (trž̌šta) ili jeftine radne snage (Stiperski, 1995.; Braičić, 2014.).

Odnos stanovništva i ekonomije može biti u inverziji, tj. neke djelatnosti utječu na raspodjelu stanovništva. Hoover (1936.) u tom pogledu razlikuje „aktivne“ $i$ „pasivne“ djelatnosti. Aktivne su one djelatnosti koje imaju aktivan utjecaj na razmještaj stanovništva, dok se pasivne djelatnosti prilagođavaju razmještaju stanovništva. Primjerice, industrija je djelatnost koja je u nas tijekom druge polovine prošlog stoljeća aktivno utjecala na promjenu razmještaja stanovništva. Kao pasivne djelatnosti mogu se spomenuti trgovina na malo, lokalne zdravstvene usluge i dr.

U ekonomskom razvoju Hrvatske dinamično je razdoblje započeto sredinom 20. stoljeća, te je osobito bilo intenzivno šezdesetih i, u nešto manjoj dinamici, sedamdesetih godina prošlog stoljeća. To je razdoblje snažne industrijalizacije, temeljene na industrijskim gigantima, uz koju su se ubrzano počele razvijati i djelatnosti uslužnog sektora (Pejnović, 2004.). Koncentracija industrije u većim gradovima i tadašnjim općinskim središtima (Magaš, 2013.) imala je za posljedicu snažnu prostornu polarizaciju industrije i radnih mjesta. $\mathrm{U}$ potrazi za poslom odvijale su se masovne, lokalne i regionalne, migracije stanovništva iz sela u gradove (Feletar, 1983.). Tako je urbano usmjerena industrijalizacija dovela ne samo do izražene koncentracije radnih mjesta u hrvatskim gradovima već i do oblikovanja novog prostornog razmještaja stanovništva (Feletar, 1983.; Vresk, 1985). Od početka 1980-ih godina javljaju se prve naznake deindustrijalizacije uz jačanje tercijarizacije (Peračković, 2011.), a preseljenja stanovništva iz sela u gradove slabe (Klempić-Bogadi, 2010.). 
Kraj 20. stoljeća u Hrvatskoj obilježen je počecima gospodarske tranzicije, ali i ratnom agresijom, tijekom koje su značajni proizvodni kapaciteti uništeni. Procesi tranzicije obilježeni su privatizacijom, smanjenjem zaposlenosti, intenziviranjem deindustrijalizacije i tercijarizacije (Peračković, 2011.). U tom razdoblju nestaju veliki proizvodni kapaciteti, a jača razvoj manjih tvrtki (Lončar i Stiperski, 2019.). U novim uvjetima dolazi do značajnih promjena u prostornom razmještaju proizvodnih kapaciteta koje su obilježene daljnjom polarizacijom tj. jačanjem nacionalnog i regionalnog monocentrizma (Feletar i Glamuzina, 2002.). Osim toga u tranziciji se javljaju i neke nove mogućnosti prostorne lokacije ekonomskih djelatnosti. Dok je do devedesetih godina prošlog stoljeća Hrvatsku obilježila izrazita koncentracija radnih mjesta i stanovnika u gradovima, potkraj prošlog stoljeća intenzivira se njihova suburbanizacija, odnosno dolazi do relociranja radnih mjesta u okolicu gradova (Klempić-Bogadi, 2010.). U tom se razdoblju, nadalje, planski osnivaju poduzetničke zone čijim se uređenjem na teritoriju neke općine ili grada želi potaknuti razvoj malog i srednjeg poduzetništva (Lončar i Stiperski, 2019.). Nove mogućnosti lokacije ekonomskih djelatnosti pružila je i izgradnja mreže autocesta u vidu koncentracije ekonomskih aktivnosti oko autocestovnih čvorova (npr. izgradnja poduzetničkih ili industrijskih zona) (Sić, 2009.). Opisani procesi ekonomske tranzicije, kao i ratna zbivanja, doveli su također do promjena u prostornom razmještaju stanovništva. Dolazi do koncentracije stanovništva u Zagrebu, a povoljniji demografski razvoj imala su i pojedina županijska središta više razine (Feletar i Stiperski, 1997.).

Polazna je točka ovog rada klasifikacija ekonomskih aktivnosti prema njihovoj geografskoj distribuciji. Porter (2003.) razlikuje sljedeće skupine djelatnosti: djelatnosti ovisne o prirodnim resursima (njihov smještaj u prostoru determiniran je potrebnim prirodnim resursima, npr. rudarstvo), lokalne djelatnosti (ravnomjerno su raspoređene u prostoru po svim regijama jedne zemlje, npr. trgovina na malo) i nadregionalne ili "traded “ djelatnosti (koncentriraju se u određenim regijama, a svoje proizvode ili usluge prodaju u raznim regijama ili zemljama, npr. proizvodnja dijelova za automobilsku industriju). $\mathrm{U}$ fokusu su interesa ovog rada djelatnosti koje su disperzirane po nacionalnom teritoriju - lokalne djelatnosti. Budući da su posrijedi djelatnosti koje primarno služe lokalnom tržištu, zaposlenost je u njima proporcionalna veličini regije odnosno njezinu stanovništvu (Porter, 2003.; Delgado, Bryden i Zyontz, 2014.).

Cilj je rada identificirati lokalne ekonomske djelatnosti u Hrvatskoj, odnosno djelatnosti koje svoj raspored u prostoru prilagođavaju prostornoj distribuciji stanovništva. Njegova je svrha pridonijeti boljem poznavanju odnosa prostorne distribucije ekonomskih djelatnosti i stanovništva. Pritom su postavljeni sljedeći radni zadaci:

- utvrditi ekonomske djelatnosti, odnosno područja djelatnosti koja su ravnomjerno distribuirana u prostoru, približno proporcionalno udjelima županijskih površina u nacionalnom teritoriju 
- utvrditi ekonomske djelatnosti, odnosno područja djelatnosti koja su u prostoru distribuirana slično kao stanovništvo, proporcionalno udjelima stanovništva pojedinih županija u stanovništvu Hrvatske

- utvrditi ekonomske djelatnosti, odnosno područja djelatnosti koja su u prostoru distribuirana slično kao stanovništvo, proporcionalno udjelima stanovništva općina i gradova u ukupnom stanovništvu Hrvatske te u stanovništvu pojedinih županija.

\section{Osvrt na dosadašnja istraživanja}

Lokacijama ekonomskih djelatnosti u prostoru posvećena je značajna pažnja u svjetskoj literaturi. Ovise li odluke o lokaciji poduzeća o njihovoj djelatnosti istražili su Ferreira i sur. (2016.). Niz je objavljenih radova koji su posvećeni zakonitostima lokacija pojedinih ekonomskih djelatnosti, npr. o lokaciji prerađivačke industrije (Latham, 1976.; Schmenner, Huber i Cook, 1987.; Duranton i Overman, 2008.; Tate i sur., 2014.; Krenz, 2016.), zatim o lokaciji uslužnih djelatnosti (Schmenner, 1994.; Cuadrado-Roura, 2013.), trgovine na malo (Mazze, 1972.; Indarti, 2004.), poslovnih usluga (Rubalcaba i sur., 2013.), tvrtki visokih tehnologija (Galbraith i De Noble, 1988.) itd.

U svjetskoj je literaturi cijeli niz radova posvećen odnosima stanovništva i ekonomije. Za ovo su istraživanje osobito značajni radovi koji pažnju posvećuju međuodnosima stanovništva (radna snaga, tržište i sl.) i lokacije ekonomske aktivnosti u prostoru. $\mathrm{O}$ radnoj snazi kao čimbeniku lokacije, odnosno njezinoj dostupnosti, cijeni i produktivnosti, progovaraju Djwa (1960.), Blair i Premus (1999.), Ramstetter (2013.), Kimelberg (2014.), Cheng (2016.) i drugi. Ulogu tržišta i lokalne potražnje na lokaciju ekonomskih aktivnosti istražili su, uz ostale, Harris (1954.), Djwa (1960.) i Justman (1994.), dok su o ekonomskoj ulozi gustoće naseljenosti radove objavili Clark (1964.), Goss i Vozikis (1994.), Yegorov (2009.) i drugi.

Od domaćih je autora zapažene radove o složenim odnosima stanovništva i ekonomskog razvoja objavila Wertheimer-Baletić (1982.; 1999.). Autorica ističe ulogu stanovništva u ekonomskom razvoju, ali i utjecaj ekonomije na demografski razvoj. Pažnja se posvećuje međuodnosima kretanja stanovništva (prirodnog i prostornog) i ekonomije, kao i važnosti različitih strukturnih obilježja stanovništva za ekonomski razvitak. I drugi domaći autori u pojedinim radovima raspravljaju o utjecaju stanovništva na ekonomski razvoj (npr. Crnković-Pozaić, 1991.) ili o utjecaju ekonomskih aktivnosti i razvoja na stanovništvo (npr. Feletar, 1983.; Feletar i Stiperski, 1997.; Pejnović, 2004.).

Sustavni prikaz razmještaja i prostorne koncentracije ekonomskih aktivnosti u $\mathrm{Hr}$ vatskoj donose Braičić i Lončar (2018). Kada je riječ o prostornoj distribuciji pojedi- 
nih ekonomskih djelatnosti u Hrvatskoj, više je pažnje posvećeno industriji (Žuljić, 1966.; Feletar i Stiperski, 1991.), a nekoliko je radova objavljeno i na temu lokacijskih čimbenika industrije u nas (Stiperski, 1995.; Braičić, 2014.). Osim radova o lokaciji ekonomskih djelatnosti, za ovo su istraživanje relevantni i radovi o problematici prostornog razmještaja stanovništva Hrvatske (Nejašmić i Toskić, 2000.; Nejašmić, 2008.).

\section{Metodologija}

Analize se temelje na podacima o broju zaposlenih u pravnim osobama koji su objavljeni u publikaciji Državnog zavoda za statistiku Zaposlenost i plaće za 2010. i 2017. godinu, a obuhvaćaju izračun relevantnih pokazatelja za 19 područja djelatnosti (Odluka o Nacionalnoj klasifikaciji djelatnosti 2007. [NKD 2007.], NN 58/07). Iz gore definiranih radnih zadataka razvidno je da su u analizama korišteni podaci o broju zaposlenih za dvije kategorije prostornih jedinica: županija te općina/gradova. U prvom slučaju županije su manje prostorne cjeline koje se kompariraju s Republikom Hrvatskom kao većom prostornom cjelinom, dok su u drugom slučaju manje prostorne cjeline općine i gradovi koje su komparirane s Hrvatskom ili pojedinim županijama kao većim prostornim cjelinama.

U svrhu identificiranja lokalnih ekonomskih djelatnosti korištena su dva pokazatelja - prostorni Ginijev koeficijent i tzv. populacijski Ginijev koeficijent. Oba primijenjena pokazatelja predstavljaju modifikacije lokacijskog Ginijevog koeficijenta, čiju je primjenu predložio Krugman (1991.). Lokacijski Ginijev koeficijent uspoređuje prostornu raspodjelu zaposlenosti u pojedinih gospodarskim djelatnostima s raspodjelom ukupne zaposlenosti (Krugman, 1991.). Njegova primjena pretpostavlja izračun lokacijskih kvocijenata, pri čemu se kao baza uzima ukupna zaposlenost (Kim, 1995.). Prostorna distribucija zaposlenosti u nekoj djelatnosti u manjoj ili većoj mjeri odstupa od distribucije ukupne zaposlenosti, koja predstavlja referentnu vrijednost. Za razliku od lokacijskog Ginijeva koeficijenta, pokazatelji korišteni u ovom radu uspoređuju prostornu raspodjelu zaposlenosti u pojedinim djelatnostima s veličinom (površinom) regija, odnosno s prostornim rasporedom stanovništva. Stoga njihova primjena zahtijeva izračun lokacijskih kvocijenata na način da se umjesto ukupne zaposlenosti kao baza uzme površina ili ukupno stanovništvo (Isard i sur., 1998.). Oba pokazatelja mogu poprimiti vrijednosti od 0 do 1 , pri čemu vrijednost bliža nuli upućuje na to da je posrijedi djelatnost koja je u prostoru distribuirana približno proporcionalno površinama regija ili proporcionalno razmještaju stanovništva (lokalne djelatnosti). Primjenu pokazatelja za mjerenje regionalnih nejednakosti koji se ponderiraju s udjelima regija u nacionalnom stanovništvu vjerojatno je prvi predložio Williamson (1965., prema Gluschenko, 2018.).

Prostorni Ginijev koeficijent $(G)$ uspoređuje geografsku raspodjelu zaposlenosti u određenim djelatnostima s veličinom, odnosno površinom regija (Sternberg i Litzenberger, 
2004.; Hagemann i sur., 2011.). Izračun obuhvaća sljedeće korake (prema Isard i sur., 1998.; Eliasson, Hansson i Lindvert, 2012. prilagodili Braičić i Lončar, 2018.):

$$
\text { (1) } L Q_{a}=\left(E_{i j} / E_{i}\right) /\left(A_{j} / A\right)
$$

pri čemu je $L Q_{a}$ lokacijski kvocijent, $E_{i j}$ broj zaposlenih u djelatnosti $i$ u manjoj cjelini $j$ (županija), $E_{i}$ broj zaposlenih u djelatnosti $i$ u većoj cjelini (Hrvatska), $A_{j}$ površina manje prostorne cjeline $j$ (županija), $A$ površina veće prostorne cjeline (Hrvatska)

$$
\text { (2) } G_{a}=1-\sum_{k=1}^{n}\left(y_{k}-y_{k-1}\right)\left(x_{i, k}+x_{i, k-1}\right)
$$

pri čemu je $G_{a}$ prostorni Ginijev koeficijent, $k$ manja cjelina $j$ rangirana prema vrijednosti lokacijskoga kvocijenta, $y_{k}$ kumulativni udio manje cjeline $k$ u ukupnoj površini veće cjeline, $x_{i, k}$ kumulativni udio manje cjeline $k \mathrm{u}$ ukupnom broju zaposlenih $\mathrm{u}$ djelatnosti $i$ veće cjeline.

Osim veličine regija, referentna vrijednost može biti i stanovništvo. Pokazatelj koji uspoređuje prostornu raspodjelu zaposlenosti u određenim djelatnostima s prostornim rasporedom stanovništva u ovom se radu naziva populacijski Ginijev koeficijent $\left(G_{p}\right)$. Primjeni tog pokazatelja također prethodi izračun lokacijskih kvocijenata (prilagodeno prema Isard i sur., 1998.; Eliasson i sur., 2012.):

$$
\text { (1) } L Q_{p}=\left(E_{i j} / E_{i}\right) /\left(P_{j} / P\right)
$$

pri čemu je $L Q_{p}$ lokacijski kvocijent, $E_{i j}$ broj zaposlenih u djelatnosti $i$ u manjoj cjelini $j$ (općina/grad ili županija), $E_{i}$ broj zaposlenih u djelatnosti $i$ u većoj cjelini (županija ili Hrvatska), $P$ broj stanovnika manje prostorne cjeline $j$ (općina/grad ili županija), $P$ broj stanovnika veće prostorne cjeline (županija ili Hrvatska)

$$
\text { (2) } G_{p}=1-\sum_{k=1}^{n}\left(z_{k}-z_{k-1}\right)\left(x_{i, k}+x_{i, k-1}\right)
$$

pri čemu je $G_{p}$ populacijski Ginijev koeficijent, $k$ manja cjelina $j$ rangirana prema vrijednosti lokacijskoga kvocijenta, $z_{k}$ kumulativni udio manje cjeline $k$ u ukupnom broju stanovnika veće cjeline, $x_{i, k}$ kumulativni udio manje cjeline $k \mathrm{u}$ ukupnom broju zaposlenih u djelatnosti $i$ veće cjeline. 


\section{Rezultati i rasprava}

\subsection{Prostorni raspored stanovništva i zaposlenosti u Hrvatskoj}

Hrvatska je prilično neravnomjerno naseljena zemlja. Razmještaj stanovništva odredili su geografski, društveno-gospodarski, politički, endogeni demografski čimbenici (bioreprodukcija i migracije), ali i naslijeđena struktura naselja (Nejašmić, 2008.). Prema Državnom zavodu za statistiku [DZS] (2019.), Hrvatska je 2017. godine imala oko 4,1 milijun stanovnika (procjena na dan 31.12.), pri čemu je čak 14 županija imalo manji udio u stanovništvu nego u površini države (tablica 1). Izuzetak su Zagrebačka, Krapinsko-zagorska, Varaždinska, Primorsko-goranska, Splitsko-dalmatinska, Istarska županija te Grad Zagreb, koje su imale veće udjele u stanovništvu nego u površini. Naročito odskače Grad Zagreb, koji zauzima 1,1\% površine Hrvatske, ali je u njemu koncentrirano 19,6\% stanovnika zemlje. Nasuprot Gradu Zagrebu je Ličko-senjska županija, najveća u zemlji, u kojoj na 9,5\% površine Hrvatske obitava 1,1\% stanovnika.

Razlike u razmještaju stanovništva po županijama u velikoj su mjeri posljedica koncentracije naseljenosti oko manjeg broja (većih) središnjih naselja od sredine 20. stoljeća (Nejašmić, 2008.) te ratnih zbivanja u njegovu posljednjem desetljeću. $S$ jedne strane oblikovani su prostori gušće naseljenosti, kojima danas pripadaju sjeverozapadna Hrvatska te županije u kojima su gradske aglomeracije žarišta razvoja (Pejnović i Kordej-De Villa, 2015.). S druge strane depopulacijski su procesi bili osobito intenzivni u županijama sa slabije razvijenim središnjim naseljem i izvan zone jačeg utjecaja makroregionalnog središta (Pejnović, 2004.; Pejnović i Kordej-De Villa, 2015.). Domovinski je rat pridonio produbljivanju depopulacije, čime su najviše bile pogođene pogranične županije (Pejnović, 2004). Time su oblikovani prostori pretežno rijetke naseljenosti.

Raspored zaposlenosti, odnosno radnih mjesta još je neravnomjerniji od naseljenosti. Veće udjele u broju zaposlenih nego u površini Hrvatske imaju Zagrebačka, Krapinsko-zagorska, Varaždinska, Primorsko-goranska, Splitsko-dalmatinska, Istarska, Međimurska županija i Grad Zagreb. Gotovo 30\% radnih mjesta u pravnim osobama Hrvatske koncentrirano je u Gradu Zagrebu. Ako se usporede udjeli županija u zaposlenosti i stanovništvu Hrvatske, tek se pet županija ističe većim udjelima u broju zaposlenih nego u broju stanovnika - Varaždinska, Primorsko-goranska, Istarska, Međimurska i Grad Zagreb. Posrijedi su županije koje su se ekonomski brže razvijale ostvarivši snažnije veze s razvijenim regijama u Europi (Sić, 2003.). 
Tablica 1.

Površina, stanovništvo i zaposlenost u pravnim osobama po županijama Republike Hrvatske 2017. godine

\begin{tabular}{|c|c|c|c|c|c|c|}
\hline \multirow[b]{2}{*}{ Županija } & \multirow[b]{2}{*}{$\begin{array}{l}\text { Površina u } \\
\mathrm{km}^{2}\end{array}$} & \multirow{2}{*}{$\begin{array}{c}\text { Broj } \\
\text { stanovnika } \\
\text { (procjena } \\
\text { 31. 12.) }\end{array}$} & \multirow[b]{2}{*}{$\begin{array}{c}\text { Broj } \\
\text { zaposlenih }\end{array}$} & \multicolumn{3}{|c|}{ Udio (\%) } \\
\hline & & & & površine & stanovnika & zaposlenih \\
\hline Zagrebačka & 3.060 & 310.561 & 65.982 & 5,4 & 7,6 & 6,2 \\
\hline Krapinsko-zagorska & 1.229 & 125.849 & 27.575 & 2,2 & 3,1 & 2,6 \\
\hline Sisačko-moslavačka & 4.468 & 150.444 & 28.978 & 7,9 & 3,7 & 2,7 \\
\hline Karlovačka & 3.626 & 117.453 & 27.493 & 6,4 & 2,9 & 2,6 \\
\hline Varaždinska & 1.262 & 167.768 & 48.497 & 2,2 & 4,1 & 4,5 \\
\hline Koprivničko-križevačka & 1.748 & 108.454 & 22.412 & 3,1 & 2,6 & 2,1 \\
\hline Bjelovarsko-bilogorska & 2.640 & 108.829 & 22.100 & 4,7 & 2,7 & 2,1 \\
\hline Primorsko-goranska & 3.588 & 285.432 & 79.300 & 6,3 & 7,0 & 7,4 \\
\hline Ličko-senjska & 5.353 & 45.450 & 10.241 & 9,5 & 1,1 & 1,0 \\
\hline Virovitičko-podravska & 2.024 & 76.131 & 13.692 & 3,6 & 1,9 & 1,3 \\
\hline Požeško-slavonska & 1.823 & 68.708 & 13.387 & 3,2 & 1,7 & 1,3 \\
\hline Brodsko-posavska & 2.030 & 141.857 & 25.921 & 3,6 & 3,5 & 2,4 \\
\hline Zadarska & 3.646 & 168.302 & 33.809 & 6,4 & 4,1 & 3,2 \\
\hline Osječko-baranjska & 4.155 & 280.145 & 65.348 & 7,3 & 6,8 & 6,1 \\
\hline Šibensko-kninska & 2.984 & 100.695 & 21.449 & 5,3 & 2,5 & 2,0 \\
\hline Vukovarsko-srijemska & 2.454 & 156.599 & 30.107 & 4,3 & 3,8 & 2,8 \\
\hline Splitsko-dalmatinska & 4.540 & 448.812 & 99.477 & 8,0 & 10,9 & 9,3 \\
\hline Istarska & 2.813 & 208.323 & 58.037 & 5,0 & 5,1 & 5,4 \\
\hline Dubrovačko-neretvanska & 1.781 & 121.325 & 28.164 & 3,1 & 3,0 & 2,6 \\
\hline Međimurska & 729 & 110.456 & 29.052 & 1,3 & 2,7 & 2,7 \\
\hline Grad Zagreb & 641 & 803.900 & 318.882 & 1,1 & 19,6 & 29,8 \\
\hline Hrvatska & 56.594 & 4.105 .493 & 1.069 .903 & 100,0 & 100,0 & 100,0 \\
\hline
\end{tabular}

Izvor: Državni zavod za statistiku [DZS] (2018.a); DZS (2018.b); DZS (2019.)

\subsection{Identifikacija lokalnih djelatnosti zasnovana na županijama kao prostornim jedinicama analize}

Gospodarske djelatnosti koje imaju vrijednosti prostornog Ginijeva koeficijenta bliže nuli ravnomjernije su raspoređene u prostoru, odnosno distribuirane su približno proporcionalno udjelima županija u površini Hrvatske (u teritorijalno većim županijama više je i zaposlenih). Ako je vrijednost koeficijenta bliža jedinici, djelatnost nije ravnomjerno raspoređena po županijama, odnosno djelatnost je koncentrirana u teritorijalno manjim županijama (Braičić i Lončar, 2018.). U tablici 2 djelatnosti su rangirane prema vrijednosti prostornog Ginijeva koeficijenta na način da se pri vrhu nalaze djelatnosti koje su u 2017. godini bile ravnomjernije distribuirane po hrvatskim županijama. Posrijedi su sljedeće djelatnosti: opskrba vodom, uklanjanje otpadnih voda, gospodarenje otpadom te djelatnosti sanacije okoliša; poljoprivreda, šumarstvo i ribarstvo; opskrba električnom energijom, plinom i parom te klimatizaci- 
ja; obrazovanje itd. S druge strane, pri dnu se tablice nalaze prostorno najviše koncentrirane djelatnosti: informacije i komunikacije, poslovanje nekretninama, financijske djelatnosti i djelatnosti osiguranja, administrativne i pomoćne uslužne djelatnosti itd. Tim je djelatnostima svojstvena koncentracija zaposlenosti u glavnom gradu Hrvatske Zagrebu, a neke su od njih usto značajnije koncentrirane i u pojedinim primorskim županijama (Braičić i Lončar, 2018.). Posrijedi su djelatnosti koje se lociraju u određenim područjima zahvaljujući svojoj konkurentnosti i atraktivnosti (Garanti, 2013.).

Osim za pojedine djelatnosti, izračun prostornog Ginijeva koeficijenta izvršen je za stanovništvo te ukupnu zaposlenost. Rezultati ukazuju na to da je stanovništvo ravnomjernije raspoređeno u prostoru od ukupne zaposlenosti. Štoviše, svega tri djelatnosti imaju niže vrijednosti Ginijeva koeficijenta nego stanovnišstvo (opskrba vodom, uklanjanje otpadnih voda, gospodarenje otpadom te djelatnosti sanacije okoliša; poljoprivreda, šumarstvo i ribarstvo; opskrba električnom energijom, plinom i parom te klimatizacija) te su jedine ravnomjernije distribuirane po županijama od stanovništva. Slične rezultate polučila su i neka istraživanja u svijetu, npr. Litzenberger i Sternberg (2005.) u Njemačkoj.

Tablica 2.

Prostorna koncentracija zaposlenosti, po područjima djelatnosti, i stanovništva u Hrvatskoj prema prostornom Ginijevom koeficijentu u 2017. godini (referentna vrijednost = površina županija)

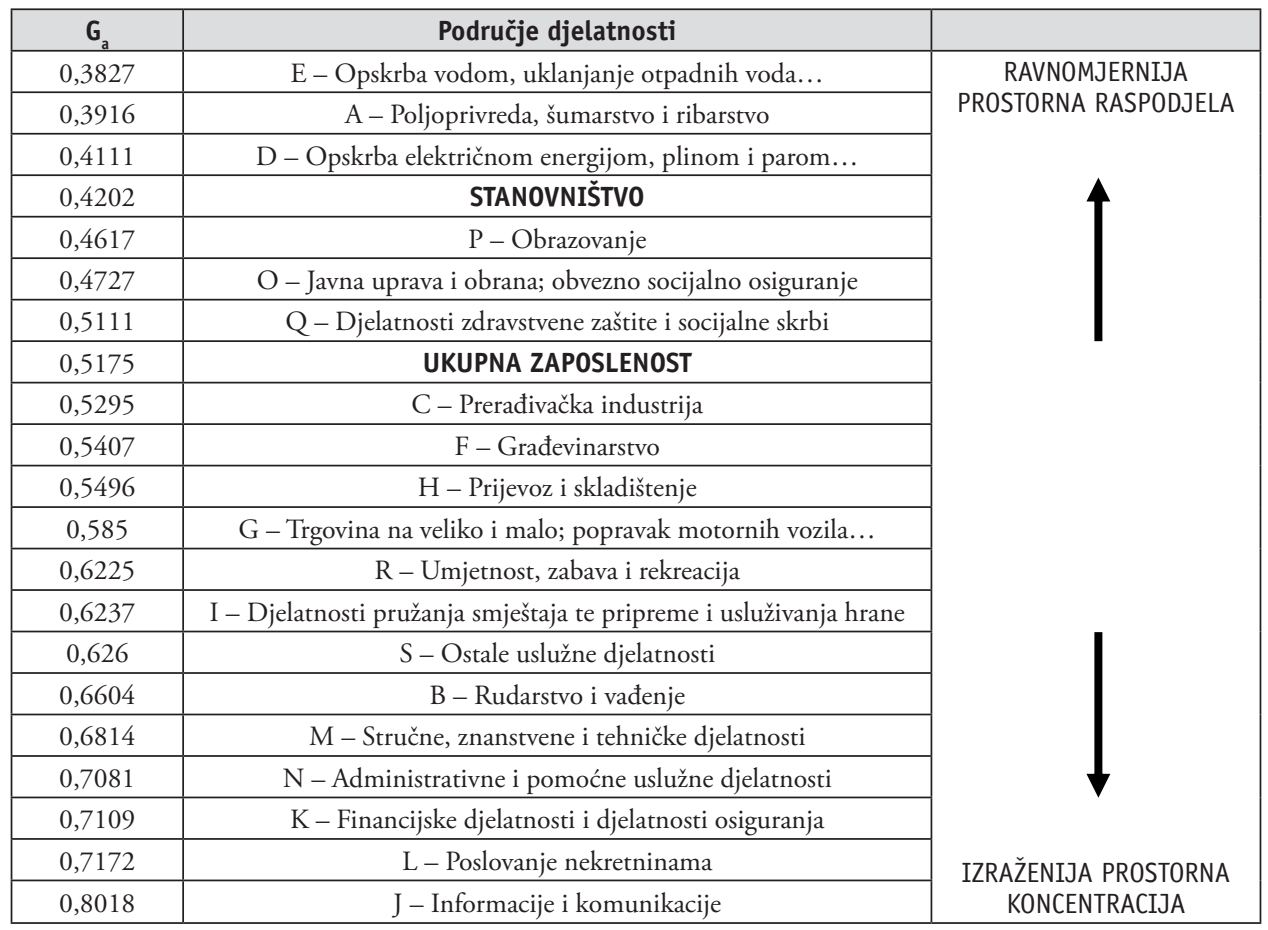

Izvor: izračun autora prema DZS (2018.a) 
Korištenjem podataka o broju zaposlenih po županijama u 2017. godini u nastavku je primjenom populacijskog Ginijeva koeficijenta prostorna raspodjela gospodarskih djelatnosti komparirana s prostornim rasporedom stanovništva. Kada bi raspodjela djelatnosti po županijama bila proporcionalna raspodjeli stanovništva, koeficijent bi iznosio 0 . Koeficijent će se približiti vrijednosti 1 ako je djelatnost u potpunosti koncentrirana u županiji s najmanje stanovnika. Pri vrhu tablice 3 nalaze se djelatnosti koje su prostorno distribuirane slično kao i stanovništvo. Vrijednosti populacijskog Ginijeva koeficijenta niže od 0,2 utvrđene su za sljedeće djelatnosti: obrazovanje, opskrba električnom energijom, plinom i parom te klimatizacija, građevinarstvo, opskrba vodom, uklanjanje otpadnih voda te zdravstvena zaštita i socijalna skrb. Obrazovanje je djelatnost koja je na prostoru Hrvatske distribuirana „najsličnije“ stanovništvu. Navedene djelatnosti osiguravaju robe i usluge za lokalno stanovništvo (Campos, 2012.; Garanti, 2013.), te ih se, uvjetno rečeno, može nazvati lokalnim djelatnostima. Pojedine djelatnosti koje imaju nešto višu vrijednost populacijskog Ginijeva koeficijenta (npr. između 0,2 i 0,3) također možemo smatrati lokalnim djelatnostima. Primjerice, trgovina na malo jest tipična lokalna djelatnost, ali je dio jedinstvenog područja djelatnosti $G$, koje ima višu vrijednost koeficijenta. To područje djelatnosti, uz ostalo, obuhvaća i djelatnost trgovine na veliko, čija lokacijska struktura manje ovisi o razmještaju stanovništva. Lokacijska struktura trgovine na malo određena je gustoćom naseljenosti, prihodima stanovništva, njegovim prometnim mogućnostima itd. (Rolph, 1932.).

\section{Tablica 3.}

Prostorna koncentracija zaposlenosti u Hrvatskoj prema populacijskom Ginijevom koeficijentu po područjima djelatnosti u 2017. godini (referentna vrijednost = stanovništvo županija)

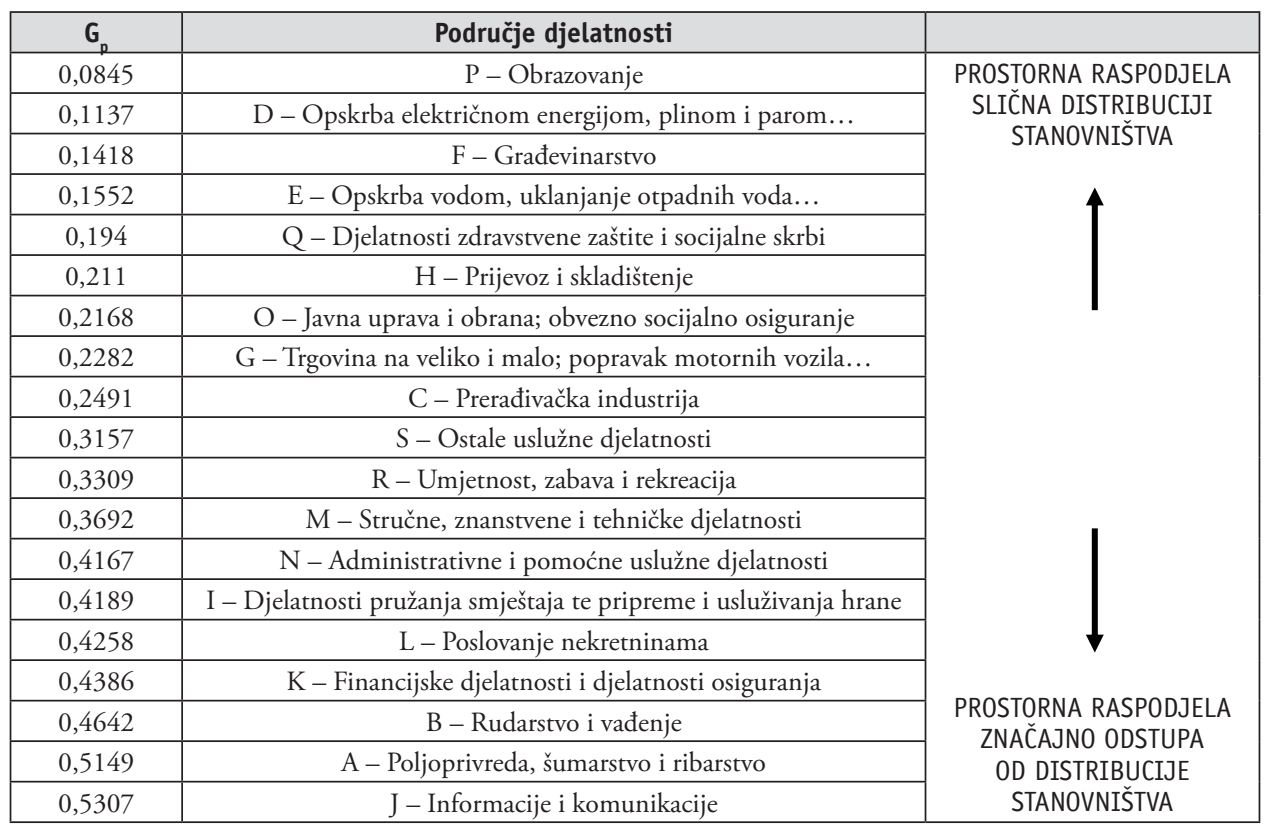

Izvor: izračun autora prema DZS (2018.a) 
Prostorni raspored djelatnosti kod kojih je populacijski Ginijev koeficijent viši od 0,4 značajnije odstupa od distribucije stanovništva. Pritom je moguće uočiti dvije skupine djelatnosti. Jednu čine djelatnosti čija prostorna distribucija ovisi o prirodnim resursima: poljoprivreda, šumarstvo i ribarstvo te rudarstvo i vađenje. Primjerice, ribarstvo je koncentrirano u županijama uz obalu Jadranskog mora, a poljoprivreda u nizinskom dijelu Hrvatske. Drugu skupinu čine djelatnosti koje se većinom lociraju u županijama zahvaljujući svojim konkurentskim prednostima (Garanti, 2013.): informacije i komunikacije, financijske djelatnosti i djelatnosti osiguranja, poslovanje nekretninama i djelatnosti pružanja smještaja te pripreme i usluživanja hrane. Primjera radi, izrazita je koncentracija informacijsko-komunikacijskih i financijskih djelatnosti u Gradu Zagrebu (Braičić i Lončar, 2018.).

Neka istraživanja ukazuju na postojanje razlika između lokalnih i ostalih (nadregionalnih) djelatnosti u pogledu zaposlenosti, produktivnosti, visine plaća itd. U lokalnim je djelatnostima u načelu zaposleno više ljudi, ali su im svojstvene niža produktivnost i niža prosječna plaća (Porter, 2003.).

U nastavku su prema vrijednostima populacijskog Ginijevog koeficijenta područja djelatnosti razvrstana u četiri skupine (tablica 4). U prvoj i drugoj skupini nalaze se djelatnosti s manjim vrijednostima istog koeficijenta $\left(G_{p}<0,3\right)$. U njima je 2017. godine bilo zaposleno 76,3\% ukupnog broja zaposlenih u pravnim osobama Hrvatske. Posrijedi su područja djelatnosti čiji se raspored u prostoru u značajnoj mjeri poklapa $s$ rasporedom stanovništva. U djelatnostima koje imaju najviše vrijednosti populacijskog Ginijevog koeficijenta $\left(G_{p}>0,4\right)$ svega je 16,6\% ukupno zaposlenih.

Usporede li se podaci za 2010. i 2017. godinu, zapaža se smanjenje broja zaposlenih u svim skupinama djelatnosti osim u skupini $s$ visokim vrijednostima populacijskog Ginijevog koeficijenta $\left(G_{p}>4,0\right)$. Zaposlenost je, prema tome, smanjena u skupini pretežno lokalnih djelatnosti, dok je u skupini djelatnosti veće prostorne koncentracije zaposlenost porasla. Na sličan je rezultat ukazalo istraživanje u Rumunjskoj, u kojem su autori istaknuli da su djelatnosti veće prostorne koncentracije u uvjetima globalne ekonomske krize ostvarile bolje rezultate u odnosu na ostatak ekonomije koji čine lokalne djelatnosti (Török i Török, 2016.).

No, usprkos toj generalizaciji, valja istaći da u svakoj od skupina postoje djelatnosti u kojima se zaposlenost povećava ili smanjuje. Iako je zaposlenost u većini djelatnosti prve i druge skupine smanjena, zanimljiv je podatak da je u nekim tipično lokalnim djelatnostima ostvaren rast zaposlenosti - u djelatnostima zdravstvene zaštite i obrazovanja. S druge strane, među djelatnostima četvrte skupine postoje djelatnosti u kojima je zaposlenost smanjena, npr. u rudarstvu i vađenju, poljoprivredi, ali i u financijskim djelatnostima i osiguranju. Drugim riječima, u ovom je razdoblju zaposlenost većinom rasla u tržišnim uslužnim djelatnostima, uz financijske djelatnosti kao izuzetak 
(HZZ, 2018.), te u djelatnostima javnog sektora financiranim iz državnog proračuna. Pad je zaposlenosti u ovom razdoblju svojstven proizvodnim djelatnostima, uključujući i primarni i sekundarni sektor.

\section{Tablica 4.}

Broj zaposlenih u pravnim osobama Hrvatske po skupinama djelatnosti formiranim prema vrijednosti populacijskog Ginijeva koeficijenta (referentna vrijednost = stanovništvo županija)

\begin{tabular}{|l|c|c|c|c|c|}
\hline \multirow{2}{*}{$\begin{array}{c}\text { Skupina } \\
\text { djelatnosti }\end{array}$} & \multicolumn{2}{|c|}{ Broj zaposlenih } & \multicolumn{2}{c|}{ Udio (\%) } & $\begin{array}{c}\text { Promjena } \\
\text { 2010. - 2017. } \\
\text { u \% }\end{array}$ \\
\cline { 2 - 5 } & 2010. & 2017. & 2010. & 2017. & $-2,9$ \\
\hline$G_{p}<0,2$ & 309.461 & 300.613 & 27,8 & 28,1 & $-7,0$ \\
\hline$G_{p}=0,2-0,3$ & 554.665 & 516.012 & 49,9 & 48,2 & $-0,8$ \\
\hline$G_{p}=0,3-0,4$ & 76.494 & 75.853 & 6,9 & 7,1 & 3,8 \\
\hline$G_{p}>0,4$ & 170.955 & 177.425 & 15,4 & 16,6 & $-3,7$ \\
\hline Ukupno & 1.111 .575 & 1.069 .903 & 100,0 & 100,0 & \\
\hline
\end{tabular}

Izvor: izračun autora prema Državni zavod za statistiku [DZS] (2011.); DZS (2018.a)

\subsection{Identifikacija lokalnih djelatnosti zasnovana na općinama i gradovima kao prostornim jedinicama analize}

Identifikaciju lokalnih djelatnosti moguće je bazirati na podacima o zaposlenosti po djelatnostima i broju stanovnika u gradovima i općinama Hrvatske. Korištenjem navedenih podataka prostorna se raspodjela zaposlenosti također komparira s prostornom distribucijom stanovništva, samo umjesto županija referentnu vrijednost predstavlja stanovništvo gradova i općina.

Dok se populacijski Ginijev koeficijent zasnovan na županijama kao prostornim jedinicama analize pokazao kao osjetljiviji pokazatelj, na razini gradova i općina ukazao je na činjenicu da je malo djelatnosti koje su u prostoru Hrvatske raspoređene proporcionalno stanovništvu. Sve djelatnosti imaju više vrijednosti populacijskog Ginijeva koeficijenta kada se analiza provodi na razini gradova i općina a ne županija (tablica 5). Obrazovanje je jedina djelatnost $s$ vrijednošću populacijskog Ginijevog koeficijenta oko 0,2 , pa njezina distribucija po općinama i gradovima Hrvatske neznatno odstupa od prostorne distribucije stanovništva. Svega su još dvije djelatnosti, trgovina na veliko i malo te građevinarstvo, koje imaju vrijednost koeficijenta manju od 0,4, te ih u tom kontekstu uvjetno možemo smatrati lokalnim djelatnostima. Od prostorne distribucije stanovništva najviše odstupaju pojedine djelatnosti ovisne o prirodnim resursima, odnosno rudarstvo i vađenje te poljoprivreda, ribarstvo i šumarstvo, a slijede informacije i komunikacije, poslovanje nekretninama itd. 
Tablica 5.

Prostorna koncentracija zaposlenosti u Hrvatskoj prema populacijskom Ginijevom koeficijentu po područjima djelatnosti u 2017. godini (referentna vrijednost = stanovništvo općina/gradova)

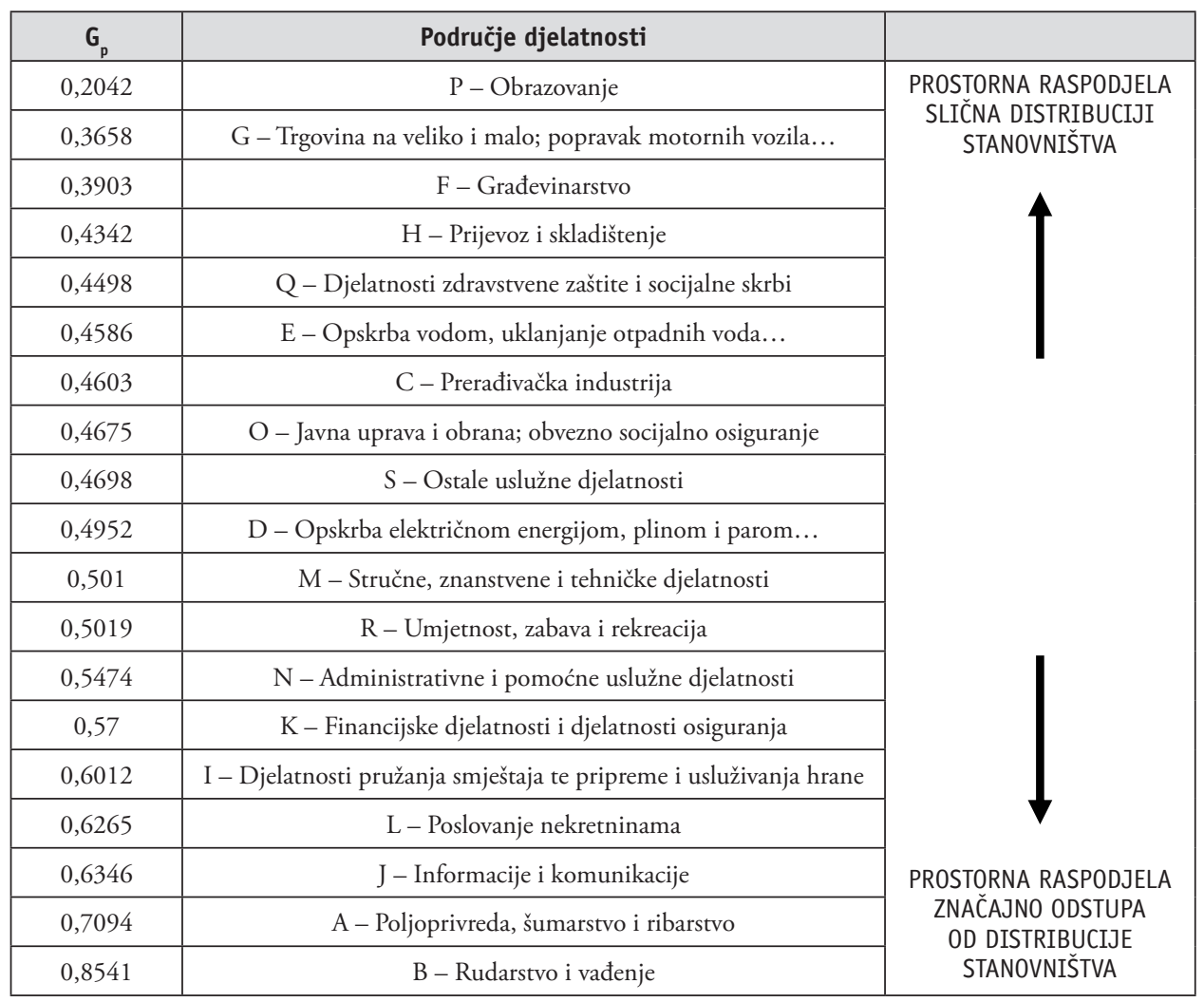

Izvor: izračun autora prema DZS (2018.a)

Analiza zasnovana na općinama i gradovima Hrvatske također je obuhvatila razvrstavanje djelatnosti prema vrijednosti populacijskog Ginijevog koeficijenta u četiri skupine. No, s obzirom na to da su vrijednosti koeficijenta za sve djelatnosti znatno više, valjalo je prethodno utvrditi nove granica razreda tj. skupina (tablica 6). U djelatnostima prve i druge skupine $\left(G_{p}<0,5\right)$ bilo je 2017. godine zaposleno 77,3\% od ukupno zaposlenih u pravnim osobama Hrvatske, dok je u djelatnostima treće i četvrte skupine $\left(G_{p}>0,5\right)$, koje imaju manju podudarnost $s$ prostornim rasporedom stanovništva, zaposleno preostalih 22,6\%. Dobiveni rezultati, prema kojima lokalne djelatnosti imaju veću zaposlenost, značajno koincidiraju s rezultatima analize bazirane na županijama. Također, zaposlenost je između 2010. i 2017. godine smanjena u skupinama pretežno lokalnih djelatnosti, dok je u skupinama djelatnosti veće prostorne koncentracije zaposlenost porasla. 
Tablica 6.

Broj zaposlenih u pravnim osobama Hrvatske po skupinama djelatnosti formiranim prema vrijednosti populacijskog Ginijeva koeficijenta (referentna vrijednost = stanovništvo općina/gradova)

\begin{tabular}{|c|c|c|c|c|c|}
\hline \multirow{2}{*}{ Skupina djelatnosti } & \multicolumn{2}{|c|}{ Broj zaposlenih } & \multicolumn{2}{|c|}{ Udio (\%) } & \multirow{2}{*}{$\begin{array}{c}\text { Promjena } \\
2010 . \text { - } \\
2017 \text {. u \% }\end{array}$} \\
\hline & 2010. & 2017. & 2010. & 2017. & \\
\hline$G_{p}<0,4$ & 365.982 & 334.302 & 32,9 & 31,2 & $-8,7$ \\
\hline$G_{p}=0,4-0,5$ & 509.749 & 493.062 & 45,9 & 46,1 & $-3,3$ \\
\hline$G_{p}=0,5-0,6$ & 133.350 & 137.163 & 12,0 & 12,8 & 2,9 \\
\hline$G_{p}>0,6$ & 102.494 & 105.376 & 9,2 & 9,8 & 2,8 \\
\hline Ukupno & 1.111 .575 & 1.069 .903 & 100,0 & 100,0 & $-3,7$ \\
\hline
\end{tabular}

Izvor: izračun autora prema Državni zavod za statistiku [DZS] (2011.); DZS (2018.a)

Naposljetku valja ukazati na korelaciju razmještaja stanovništva i ekonomskih djelatnosti unutar pojedinih županija (tablica 7). Jedina djelatnost koja u svim županijama ima vrijednost populacijskog Ginijeva koeficijenta ispod 0,2 je obrazovanje. Vrijednost koeficijenta ispod 0,4 utvrđena je nadalje u djelatnosti trgovine na veliko i malo u 16 županija, u djelatnosti opskrbe vodom u 10 županija, u djelatnosti građevinarstva u njih 9 itd. Posrijedi su područja djelatnosti koje su u mnogim županijama prostorno raspoređene sukladno rasporedu njihova stanovništva. S druge strane, prostorni raspored rudarstva i vađenja u svim se županijama bitno razlikuje od prostornog rasporeda stanovništva (vrijednosti populacijskog Ginijeva koeficijenta posvuda su iznad 0,6). Izrazita diskrepancija između rasporeda u prostoru i stanovništva također je svojstvena djelatnosti poslovanja nekretninama, koja u 13 županija ima vrijednost koeficijenta iznad 0,6.

Moguće je identificirati i djelatnosti koje su u pojedinim županijama distribuirane sukladno stanovništvu, a drugdje značajno odstupaju od njegova razmještaja. Najbolji je primjer djelatnost opskrbe vodom i uklanjanja otpadnih voda, čija je geografska distribucija u mnogim županijama sukladna distribuciji stanovništva, dok je u Krapinsko-zagorskoj diskrepancija tih dviju pojava izrazita.

Najveće poklapanje prostornog rasporeda ekonomskih djelatnosti s rasporedom stanovništva utvrđeno je u Karlovačkoj i Šibensko-kninskoj županiji, u kojima približno polovina djelatnosti ima vrijednost koeficijenta ispod 0,4 . Te se županije ubrajaju među najrjeđe naseljene u Hrvatskoj i neravnomjernog su razmještaja stanovništva. Županije s najslabijom korespondencijom rasporeda tih dviju pojava u prostoru su Međimurska, Krapinsko-zagorska i Varaždinska. Prostorni raspored većine djelatnosti značajnije odstupa od razmještaja stanovništva upravo u županijama s većom gustoćom naseljenosti njihovih općina i ujedno ravnomjernije naseljenosti. 

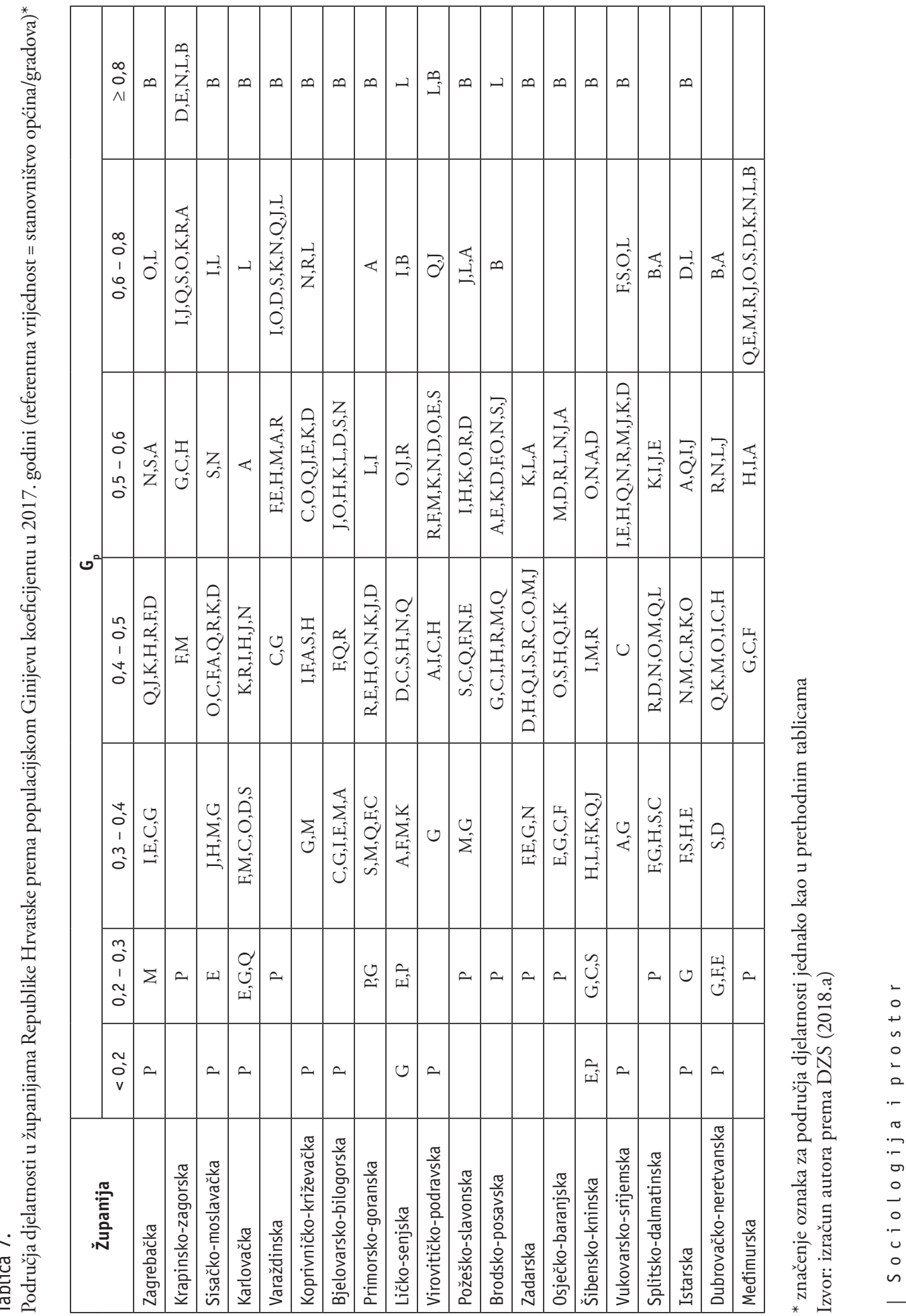


\section{Zaključak}

Stanovništvo se kao izvor radne snage ili tržište smatra značajnim lokacijskim čimbenikom ekonomskih aktivnosti u prostoru. Dok se neke djelatnosti više prilagođavaju razmještaju stanovništva, druge aktivno djeluju na prostorni prerazmještaj stanovništva. U fokusu su ovog istraživanja lokalne djelatnosti u Hrvatskoj, odnosno djelatnosti ravnomjernije raspoređene u prostoru, sukladno razmještaju stanovništva. Iako ni stanovništvo Hrvatske nije ravnomjerno raspoređeno po županijama, prostorni je raspored stanovništva ipak ravnomjerniji od distribucije zaposlenosti (radnih mjesta) u prostoru, odnosno svega je nekoliko područja djelatnosti ravnomjernije raspoređeno po županijama od stanovništva.

Analizom koja je bazirana na županijama kao prostornim analitičkim jedinicama identificiran je znatno veći broj ekonomskih djelatnosti čija je prostorna distribucija u suglasju s razmještajem stanovništva nego analizom zasnovanom na podacima na općinsko-gradskoj razini. Djelatnosti koje su po hrvatskim županijama distribuirane najsličnije distribuciji stanovništva su redom: obrazovanje; opskrba električnom energijom, plinom i parom te klimatizacija; građevinarstvo; opskrba vodom i uklanjanje otpadnih voda te djelatnosti zdravstvene zaštite i socijalne skrbi. Slijede djelatnosti vezane uz prijevoz i skladištenje, javnu upravu, trgovinu na veliko i malo itd. Ta područja djelatnosti uglavnom obuhvaćaju lokalne ekonomske djelatnosti. $S$ druge strane, jedina djelatnost koja je po općinama i gradovima Hrvatske distribuirana vrlo slično distribuciji stanovništva jest obrazovanje, što ukazuje na to da odgojno-obrazovne ustanove zalaze u sve naseljene krajeve. Slijede djelatnosti trgovine na veliko i malo te građevinarstvo. Takvi rezultati uvelike su odraz činjenice da su županije teritorijalno i demografski veće prostorne jedinice i imaju heterogeniju ekonomsku strukturu od općina. S druge strane, brojne općine imaju malo stanovnika, njihova je ekonomska struktura homogenija, a u nekima gotovo izostaje svaka ekonomska aktivnost. Kao ekstremni primjeri mogu se izdvojiti općine Ervenik i Kijevo u Šibensko-kninskoj županiji i Zažablje u Dubrovačko-neretvanskoj županiji s manje od deset radnih mjesta u pravnim osobama (DZS, 2018.a). Posljedica je izraženija nepodudarnost između distribucije djelatnosti i stanovništva po općinama i gradovima. Valja još jednom apostrofirati da djelatnost obrazovanja ujedno neznatno odstupa od raspodjele stanovništva Hrvatske po županijama, kao i od raspodjele stanovništva po gradovima i općinama. Prema tome, obrazovanje je područje djelatnosti čiji prostorni raspored zaposlenosti, u obama slučajevima, najviše koincidira s prostornom distribucijom stanovništva te predstavlja izrazito lokalnu djelatnost.

Ovo je istraživanje rezultiralo još nekim zaključcima. Uz lokalne djelatnosti, prepoznate su i dvije skupine djelatnosti čija prostorna distribucija značajnije odstupa od distribucije stanovništva. Posrijedi su djelatnosti ovisne o prirodnim resursima te djelatnosti povezane s konkurentskim prednostima pojedinih regija. Istraživanjem je također ustanovljeno da lokalne djelatnosti u Hrvatskoj zapošljavaju znatno više ljudi 
nego ostale dvije skupine djelatnosti. Najzad, uočena je i negativna korelacija suglasja geografske distribucije ekonomskih djelatnosti i stanovništva s gustoćom naseljenosti pojedinih županija - najgušće naseljene županije u Hrvatskoj (izuzimajući Grad Zagreb) imaju najmanje poklapanje geografske distribucije djelatnosti i stanovništva.

Ograničavajući čimbenik za detaljniju analizu ove problematike dostupnost je podataka o broju zaposlenih samo na razini područja djelatnosti, zbog čega su rezultati generalizirani. Naime, Nacionalna klasifikacija djelatnosti (NKD 2007., NN 58/07) obuhvaća nekoliko hijerarhijskih razina, odnosno područja djelatnosti dijele se dalje na odjeljke, unutar kojih se izdvajaju skupine te razredi. Tako se, primjerice, neke grane prerađivačke industrije lociraju u blizini tržišta (proizvodnja lako kvarljivih proizvoda poput mliječnih proizvoda, zatim tiskanje novina i sl.) i predstavljaju lokalne djelatnosti, dok s druge strane pojedine grane prerađivačke industrije teže lociranju u blizini nalazišta sirovina ili energenata (proizvodnja keramike, proizvodnja željeza i čelika i sl.) (Djwa, 1960.; Talloo, 2007.), odnosno njihov raspored u prostoru ne slijedi prostorni obrazac stanovništva. Osiguranje potrebnih podataka na razini odjeljaka djelatnosti omogućilo bi podrobniju analizu zakonitosti lokacija ekonomskih djelatnosti i njihova međuodnosa s prostornom distribucijom stanovništva, što je podloga daljnjih istraživanja ove problematike.

\section{Literatura}

1. Blair, J. P. i Premus, R. (1999). Major Factors in Industrial Location: A Review. Journal of Composite Materials, 33 (10): 928-940.

2. Braičić, Z. (2014). Suvremeni pogledi na lokacijske čimbenike malih i srednjih industrijskih poduzeća Siska i Petrinje. Hrvatski geografski glasnik, 76 (2): 39-59.

3. Braičić, Z. i Lončar, J. (2018). Prostorna koncentracija i regionalna raspodjela gospodarskih djelatnosti u Republici Hrvatskoj. Hrvatski geografski glasnik, 80 (2): 33-54.

4. Campos, C. (2012). The Geographical Concentration of Industries. London i Newport: Office for National Statistics.

5. Cheng, S. (2016). The role of labor cost in the location choices of Japanese investors in China. Papers in Regional Science, 85 (1): 121-138.

6. Clark, C. (1964). The Location of Industries and Population. Town Planning Review, 35: 195-218.

7. Cuadrado-Roura, J. R. (2013). The Location of Service Industries, in: Cuadrado-Roura Juan R. (Ed.). Service Industries and Regions. Growth, Location and Regional Effects. Berlin, Heidelberg: Springer-Verlag.

8. Crnković-Pozaić, S. (1991). Utjecaj brojnosti stanovništva na ekonomski razvitak. Ekonomski pregled, 42 (8-9): 419-430.

9. Cvitanović, A. (2002). Geografski rječnik. Zadar: Hrvatsko geografsko društvo Zadar; Matica hrvatska - Zadar; Filozofski fakultet u Zadru; Zadiz. 
10. Delgado, M.; Bryden, R. and Zyontz, S. (2014). Categorization of traded and local industries in the U.S. economy. Mimeo. https://clustermapping.us/sites/default/files/files/page/Categorization\%20of\%20Traded\%20and\%20Local\%20 Industries\%20in\%20the\%20US\%20Economy.pdf. (Pregledano 20. studenog 2019.)

11. Djwa, P. D. K. (1960). An analysis of industrial location factors with particular reference to Indonesia. Vancouver: University of British Columbia.

12. Duranton, G. and Overman, H. G. (2008). Exploring the Detailed Location Patterns of UK Manufacturing Industries Using Microgeographic Data. Journal of Regional Science, 48 (1): 213-243.

13. Feletar, D. (1983). Industrija kao faktor promjena prostorne distribucije stanovništva u Podravini. Geografski glasnik, 45: 105-117.

14. Feletar, D. and Glamuzina, M. (2002). Prostorna distribucija zaposlenosti i nezaposlenosti kao pokazatelj diferenciranosti na prostoru Hrvatske. Podravina, $1(2): 5-42$.

15. Feletar, D. i Stiperski, Z. (1992). Značenje i prostorni razmještaj industrije Hrvatske. Geografski horizont, 38 (2): 85-95.

16. Feletar, D. i Stiperski, Z. (1997). Procesi tranzicije kao faktor promjena broja i strukture stanovništva županijskih središta u Hrvatskoj. Acta Geographica Croatica, 32: 91-99.

17. Ferreira, J. J. M.; Fernandes, C. I.; Raposo, M. L.; Thurik, A. R.; Faria, J. R. (2016). Entrepreneur location decisions across industries. International entrepreneurship and management journal, 12 (4): 985-1006.

18. Eliasson, K.; Hansson, P. and Lindvert, M. (2012). Jobs and exposure to international trade within the service sector in Sweden. The World Economy, 35 (5): 578-608.

19. Galbraith, D. and De Noble, A. F. (1988). Location decisions by high technology firms: a comparison of firm size, industry type and institutional form. Entrepreneurship Theory and Practice, 13: 31-48.

20. Garanti, Z. (2013). Geographic Concentration of Economic Activities in Latvia. Middle-East Journal of Scientific Research, 17 (2): 213-218.

21. Gluschenko, H. (2018). Measuring regional inequality: to weight or not to weight? Spatial Economic Analysis, 13 (1): 36-59.

22. Goss, E. and Vozikis, G. S. (1994). High Tech Manufacturing: Firm Size, Industry and Population Density. Small Business Economics, 6 (4): 291-297.

23. Hagemann, H.; Christ, J. P.; Rukwid, R. i Erber, G. (2011): Die Bedeutung von Innovationsclustern, sektoralen und regionalen Innovationssystemen zur Stärkung der globalen Wettbewerbsfähigkeit der baden-württembergischen Wirtschaft. Hohenheim: Universität Hohenheim. https://www.baden-wuerttemberg.de/fileadmin/redaktion/dateien/Altdaten/202/2 Die Bedeutung von Innovationscluster.pdf. (Pregledano 16. srpnja 2015.) 
24. Harris, C. D. (1954). The Market as a Factor in the Localization of Industry in the United States. Annals of the Association of American Geographers, 44: 315348.

25. Hoover, E. M. (1936). The Measurement of Industrial Localization. The Review of Economics and Statistics, 18 (4): 162-171.

26. Indarti, N. (2004). Business Location and Success: The Case of Internet Cafe Business in Indonesia. Gadjah Mada International Journal of Business, 6 (2), 171-192.

27. Isard, W.; Azis, I. J.; Drennan, M. P.; Miller, R. E.; Saltzman, S.; Thorbecke, E. (1998). Methods of Interregional and Regional Analysis. Aldershot: Ashgate Publishing Company.

28. Justman, M. (1994). The Effect of Local Demand on Industry Location. Review of Economics and Statistics, 76: 742-753.

29. Kim, S. (1995). Expansion of Markets and the Geographic Distribution of Economic Activities: the Trend in U. S. Regional Manufacturing Structure, 18601987. Quarterly Journal of Economics, 110 (4): 881-908.

30. Kimelberg, S. M. (2014). Labor Needs, Crime, and the Business Location Decision: A Qualitative Account. Community Development, 45 (1): 45-59.

31. Klempić-Bogadi, S. (2010). Populacijski razvoj gradskih regija Hrvatske 1948.2001., u: Lajić, I. (Ur.). Migracije i regionalni razvoj Hrvatske. Zagreb: IMIN.

32. Krenz, A. (2016). Firm structure and the location decision of German manufacturing firms: Evidence from official firm-level data. Göttingen: University of Göttingen, Center for European, Governance and Economic Development Research.

33. Krugman, P. (1991). Geography and Trade. Cambridge, MA: MIT Press.

34. Latham, W. R. (1976). Locational behavior in manufacturing industries. Leiden: Martinus Nijhoff Social Sciences Division.

35. Litzenberger, T. and Sternberg, R. (2005). Regional clusters and entrepreneurial activities: Empirical evidence from German regions, in: Karlsson, C.; Johansson, B. and Stough, R. (Eds.). Industrial Clusters and Inter-Firm Networks. Cheltenham, Northampton: Edward Elgar Publishing.

36. Lončar, J. i Stiperski, Z. (2019). Industrijska geografija. Zagreb: Meridijani.

37. Magaš, D. (2013). Geografija Hrvatske. Zadar: Sveučilište u Zadru, Meridijani.

38. Mazze, E. M. (1972). Identifying the key factors in retail store location. Journal of Small Business and Management, 10 (1): 17-20.

39. Nejašmić, I. (2008). Stanovništvo Hrvatske: demogeografske studije i analize. Zagreb: Hrvatsko geografsko društvo.

40. Nejašmić, I. i Toskić, A. (2000). Razmještaj stanovništva u Republici Hrvatskoj - dio općih demografskih i društveno-gospodarskih procesa. Geoadria, 5: 93-104.

41. Pejnović, D. (2004). Depopulacija županija i disparitet u regionalnom razvoju Hrvatske. Društvena istraživanja, 13 (4-5): 701-726. 
42. Pejnović, D. i Kordej-De Villa, Ž. (2015). Demografski resursi kao indikator i čimbenik dispariteta u regionalnom razvoju Hrvatske. Društvena istraživanja, 24 (3): 321-343.

43. Peračković, K. (2011). Hrvatska u postindustrijsko doba - promjene u strukturi radnog aktivnoga stanovništva po sektorima djelatnosti i spolu. Društvena istraživanja, 20 (1): 89-110.

44. Porter, M. E. (2003). The Economic Performance of Regions. Regional Studies, 37 (6-7): 549-578.

45. Ramstetter, E. D. (2013). Resource and Labor Cost Differentials between Japan and Asian Host Economies and Location Decisions of Japan's Manufacturing Multinationals. Working Paper No. 2012-05. Kitakyushu: International Centre for the Study of East Asian Development.

46. Rolph, I. K. (1932). The population pattern in relation to retail buying: as exemplified in Baltimore. American Journal of Sociology, 38 (3): 368-376.

47. Rubalcaba, L.; Gallego, J.; Gallo, M. T. and Garrido, R. (2013). Business services location and market factors in major European cities. Cities, 31: 258-266.

48. Schmenner, R. W. (1994). Service firm location decisions: some Midwestern evidence. International Journal of Service Industry Management, 5 (3): 35-56.

49. Schmenner, R. W.; Huber, J. C. and Cook, R. L. (1987). Geographic Differences and the Location of New Manufacturing Facilities. Journal of Urban Economics, 21 (1): 83-104.

50. Sić, M. (2003). Regional Disparities in Croatia. Hrvatski geografski glasnik, 65 (2): 5-28.

51. Sić, M. (2009). Utjecaj autoceste Zagreb-Split na regionalni razvoj Like. Hrvatski geografski glasnik, 71 (1): 87-101.

52. Sternberg, R. and Litzenberger, T. (2004). Regional Clusters in Germany - their Geography and their Relevance for Entrepreneurial Activities. European Planning Studies, 12 (6): 767-791.

53. Stiperski, Z. (1995). Hijerarhija činitelja industrijske lokacije na primjeru zapadne Hrvatske. Prostor, 3 (1): 11-24.

54. Talloo, T. J. (2007). Business Organisation and Management: For B. COM Course of University of Delhi. New Delhi: Tata McGraw-Hill Publishing Company Limited.

55. Tate, W. L.; Ellram, L. M.; Schoenherr, T. and Petersen, K. J. (2014). Global competitive conditions driving the manufacturing location decision. Business Horizons, 57 (3): 381-390.

56. Török, I. and Török, G. (2016). The Dynamics of Traded Industries In Romania Between 2008-2014. IOP Conference Series: Earth and Environmental Science, 44: 1-6. https://iopscience.iop.org/article/10.1088/1755-1315/44/3/032023/ pdf. (Pregledano 12. listopada 2019.)

57. Vresk, M. (1985). Oblici urbanizacije i prostorna pokretljivost stanovnišva Središnje Hrvatske. Geografski glasnik, 47: 47-70. 
58. Wertheimer-Baletić, A. (1982). Demografija: stanovništvo i ekonomski razvitak. Zagreb: Informator.

59. Wertheimer-Balerić, A. (1999). Stanovništvo i razvoj. Zagreb: Mate.

60. Žuljić, S. (1966). Jedan pristup analizi prostornog razmještaja industrije (na primjeru SR Hrvatske). Geografski glasnik, 28 (1): 59-70.

61. Yegorov, Y. (2009). Socio-economic influences of population density. Chinese Business Review, 8: 1-12.

\section{Izvori}

Državni zavod za statistiku (2011). Zaposlenost i plaće u 2010. Zagreb: Državni zavod za statistiku.

Državni zavod za statistiku (2018a). Zaposlenost i plaće u 2017. Zagreb: Državni zavod za statistiku.

Državni zavod za statistiku (2018b). Statistički ljetopis Republike Hrvatske 2018. Zagreb: Državni zavod za statistiku.

Državni zavod za statistiku (2019). PC-Axis baze podataka: Procjena stanovništva prema dobnim skupinama i spolu, po županijama, 31.12.2017. Zagreb: Državni zavod za statistiku. Pregledano 13. studenog 2019. (https://www.dzs.hr/).

Hrvatski zavod za zapošljavanje (2018). Analitički bilten, 20 (4). Zagreb: Hrvatski zavod za zapošljavanje.

Odluka o Nacionalnoj klasifikaciji djelatnosti 2007. - NKD 2007., Narodne novine 58 od 2007. 
Izvorni znanstveni rad

\title{
Identifying Local Economic Activities in Croatia by the Use of Gini's Coefficient
}

\author{
Zdenko Braičić \\ University of Zagreb, Faculty of Teacher Education, Department in Petrinja, Croatia \\ e-mail: zdenko.braicic@ufzg.hr
}

\begin{abstract}
The starting point of this paper is the classification of economic activities according to their geographical distribution. Porter (2003) distinguishes traded activities, activities depending on natural resources and local activities. The aim of this paper is to establish the local economic activities (activity sections) in Croatia, which means activities whose layout in space is adjusted to spatial distribution of population. For that purpose a modified use of Gini's coefficient has been suggested, the Gini's population coefficient, which compares geographical distribution of employment in certain activities with geographical distribution of population. This has established economical activities which are distributed amongst counties in Croatia in consistence to the distribution of population (2017): education, electricity, gas, steam and air conditioning supply, water supply, human health and social work activities, etc. The second part of this paper identifies the activities which are distributed in municipalities and towns of Croatia similarly to population. Education is the activity whose geographical distribution slightly deviates from the distribution of population in Croatia by municipalities and towns. The existence of differences between local and other activities connected with employment has also been pointed out in the paper.
\end{abstract}

Key words: geographical distribution, local activities, population, Gini's population coefficient, Croatia. 